\title{
酸化エチレン異性化反応におけるコーク生成挙動の 定量的解析
}

\author{
高㟢 裕圭*, 舘川 憲雄 ${ }^{+1)}$, 佐久間 奏 ${ }^{\dagger 2}$ \\ 宇都宮大学工学部工業化学科, 321 宇都宮市石井町 2753 \\ †1) 電気化学工業 (株) 青海工場, 949-03 新潟県西頸城郡青海町 \\ †2）東洋インキ製造(株)川越第二工場，356 埼玉県川越市中福松峯
}

(昭和 59 年 9 月 3 日受理)

\begin{abstract}
触媒劣化を伴う反応に括ける，劣化関数とコーク生成量の全操作因子による表式化を試みた。シリカーアルミナ系 触媒である塩酸処理膠質土上で酸化エチレン異性化反応を行い, コーク生成現象を操作因子によって定量的に検討し た。触媒劣化現象は, 操作因子のらち供給濃度, ついで反応温度によって支配され, これらによって均一被覆, 細孔 均一閉そく, 細孔入口閉そく, 粒子間析出等を生じることと, 劣化関数は触媒の継続的反応性をも表現しうることが 明らかとなった。そして, 原料と生成物のそれぞれから生成する性質の異なるコークにおいても, 同じ型の式でコー ク量を表現することができた。
\end{abstract}

\section{1. 緒言}

シリカーアルミナ系触媒や ゼオライト触媒上での 炭化水素の 反応は, 流通時間の経過とともに反応速度が減少し, 触媒の表 面上でュークの析出を伴う。接触分解反応におけるコーク生成 の速度論は, Voorhies' ${ }^{1)}$ 以来 Pachovsky ら ${ }^{2)}$, Beekman と Froment ${ }^{3)}$, Ozawa と Bischoff ら ${ }^{4)}$ によって示されたけれど も，失活の機構はいまだよく知られていない。また，コークを 生じさせる有機反応と同時に，反応が行われる場所に対しても 議論されている。 Rollman'5), Rollman と Walsh' ${ }^{6)}$ は種々の細 孔径をもつゼオライト触媒を用い, コーク生成の程度が触媒の 内部構造により決定されるとした。さらに，Venuto と Hamilton?) は触媒の 細孔径により生成されるコークのベンゼン環 数が制限されるとした。逆に, Haldeman と Botty8) はコーク が接触分解触媒の粒子間の間隙に分布しており, 触媒失活が触 媒粒子間の払散抵抗の増加に起因しているとし，コーク生成の 主要部分は触媒粒子の外部表面で起こるとした。また，析出 コークの操作変数による検討としては，最近わずかに Sedran ら9)の研究がある。彼はメタノールから炭化水素への変換反応 において，温度が最も影響する因子であるとしているが，定量 的解析まで至っていない。

一方, 酸化エチンンの接触異性化については越後谷10)の研究 があるのみで，それもコークについては全く検討を行っていな い。1964 年以後はほとんど研究されていない。むしろ，合成繊 維ポリエステルをつくるエチレングリコールの原料として, 重 合反応の分野の研究が多数ある。的動力学的検討に対しては, 一連の酒井ら ${ }^{12)}$ の研究のほか二，三13)行われた。

本報はSedran ら ${ }^{9)}$ と類似の立場であるが，膠質土触媒にお ける酸化ェチレンの異性化反応を行い, コーク生成挙動の操作 因子による定量的解析のみ検討した。主反応解析の検討につい

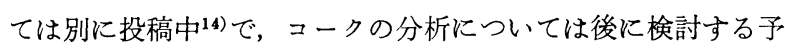
定である。

*連絡先

\section{2. 実験}

\section{$2 \cdot 1$ 触媒調製}

用いた触媒には, 杤木県内に広く産出する鹿沼土と呼ばれる 膠質土（赤褐色の大沢土）を原料とした。天然に産出した土は 磁鉄鉱や火山岩くず（輝石, 角閃石, 軽石など）を多少含んで いる。まずボールミルで粉碎後, ノーベル水賄(ひ)装置で分級 して精製膠質土を得た。これは鉱物学的にはアロフェンと呼ば れ, 非晶質シリカーアルミナー鉄ーゲルを主成分とする。化学式は $\left[\mathrm{Al}_{2} \mathrm{O}_{3} \cdot 1 \sim 3 \mathrm{SiO}_{2} \cdot 1 \sim 3 \mathrm{H}_{2} \mathrm{O}\right]($ ゲル $)+\left[m \mathrm{Al}(\mathrm{OH})_{3} \mathrm{aq} .+\right.$ $\left.n \mathrm{Fe}(\mathrm{OH})_{3} \mathrm{aq}.\right]($ ゲル)

と提唱されている16) がいまだ不明である。その成分組成（wt \%) 俚 Ig $\cdot$ loss $=18.82, \quad \mathrm{SiO}_{2}=29.65, \quad \mathrm{Al}_{2} \mathrm{O}_{3}=25.70, \quad \mathrm{Fe}_{2} \mathrm{O}_{3}$ $=11.80$ その他 $\mathrm{CaO}, \mathrm{K}_{2} \mathrm{O}, \mathrm{TiO}_{2}, \mathrm{Na}_{2} \mathrm{O}$ などで, $\mathrm{BET}$ 法 による表面積は $375 \mathrm{~km}^{2} \cdot \mathrm{kg}^{-1}$ であった。これに 8 規定塩酸を 当量の倍量加え, $353 \mathrm{~K}$ にて 2 時間反応すると, 含有するアル ミナ，鉄のほとんぞを溶出した。水洗後，乾燥し，厈縮成型 分級して調製した。成分組成 $(w t \%)$ は $\mathrm{Ig} \cdot \mathrm{loss}=5.66, \mathrm{SiO}_{2}$ =84.86, $\mathrm{Al}_{2} \mathrm{O}_{3}=5.01, \mathrm{Fe}_{2} \mathrm{O}_{3}=1.24$ であり, 比表面積 525 $\mathrm{km}^{2} \cdot \mathrm{kg}^{-1}$, 平均細孔径 $5.13 \mathrm{~nm}$, 細孔容積 $0.673 \mathrm{~mm}^{3} \cdot \mathrm{kg}^{-1}$, 全酸量 $0.322 \mathrm{~mol} \cdot \mathrm{kg}^{-1}$ (by $\mathrm{NH}_{3}, 298 \mathrm{~K}$, T.G.) であった。 なお, 触媒の粒径は外部境膜抵抗を考兄, $20 \sim 28$ mesh のもの を用いた。

\section{$2 \cdot 2$ 実験装置および方法}

実験装置は流通系微分反応装置を用い，その略図を Fig. 1 に示した。触媒を内径 13 , 外径 17 , 高さ $26 \mathrm{~mm}$ のステンレ ス製かごDに入れ，系内の天びんAに直接つり下げてその重量 を随時測定した。反応管Bは内径 $22 \mathrm{~mm}$ のパイレックス製で ある。酸化エチレンは日本触媒化学工業製の, 窒素は日本酸素 製の, アセトアルデヒドは関東化学製試薬を蒸留したもののそ れぞれシリンダーを使用した。また, 窒素以外のラインを保温 した。

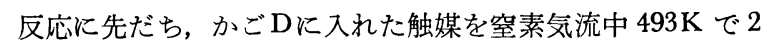




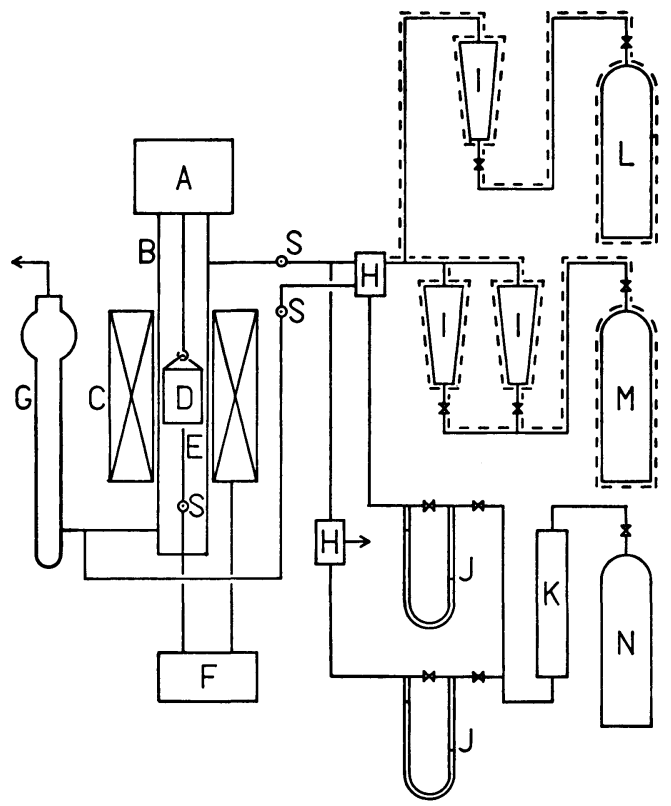

Fig. 1 Reaction system with balanı,e (A), reactor (B), electric furnace $(\mathrm{C})$, catalyst cage (D), thermocouple (E), PID temperature controller (F), soap film meter $(\mathrm{G})$, electromagnetic valve $(\mathrm{H})$, rotameter $(\mathrm{I})$, capillary flow meter $(\mathrm{J})$, deoxygen and dehydration pipe $(\mathrm{K})$, acetoaldehyde cylinder (L), ethylene-oxide cylinder (M), nitrogen cylinder $(\mathrm{N})$, sampling point $(\mathrm{S})$, and heating line (dotted line).

時間乾燥した。反応ガス組成を流量メーター I, J により設定 し, 反応器が設定温度一定になったとき, 電磁弁Hにより窒素 ガスと反応ガスとを切り換えて反応を開始した。測定時間ごと に触媒重量を天びんAで計測し，反応管出入口に設けたサンプ リングポイント Sより，マイクロシリンジでガスを採取した。 ガスの分析はガスクロマトグラフ (Yanagimoto G-80) で行 った。充てん剂は液相 $35 \%$ グリセロール，カラムは $4.8 \mathrm{~m}$, キャリヤーガスは水素で, 検出器は TCD と FID を共用し た。

\section{3. 結果と考察}

\section{1 アセトアルデヒド生成反応の劣化関数}

塩酸処理膠質土上での酸化ェチレン異性化反応はアセトアル デヒドを生成する。触媒はフレッシュな状態において淡灰色を 呈しているが，実験終了後は茶褐色ないし黒褐色を呈し，コー クの析出を示していた。また触媒重量は Fig. 7 のように時間 とともに増加し，この増加分はコーク重量に相当すると見なし た。

一般に触媒劣化の影響がある場合, 反応速度 $r$ は劣化が起こ っていない初期反応速度 $r_{0}{ }^{14)}$ と劣化関数 $\varphi$ との積として次の ように表される。

$$
r=r_{0} \cdot \varphi\left(\theta \cdot z \cdot C_{\mathrm{c}} \cdot \mathrm{W} / \mathrm{F} \cdot T\right)
$$

したがって, 劣化関数は観測される反応速度と初期反応速度と の比として与えられ，触媒の持続性とか耐久性を示している。 Anderson ${ }^{17)}$, Froment と Beeckman $ら^{3)}$ にって劣化関数に
ついて 5 関数型が報告されているが，いずれの関数型も劣化の 度合を示していると思われ, かつ劣化係数と呼ぶべき比例定数 $\alpha$ とコーク量 $C_{\mathrm{c}}$ との 2 変数のみで表されている。なお，この 反応の場合, 劣化関数の対数とコーク量とは比例関係が成立し た。 $\left(\ln \varphi=-\alpha C_{\mathrm{c}}\right)$

Fig. 2 は入口原料モル分率, 反応温度を変化させた場合の アセトアルデヒド生成反応劣化関数 $\varphi_{\mathrm{A}}$ とコーク生成量との関 係を示している。劣化関数は入口原料モル分率に依存し, 反応 温度に依存しないこと。そして同じューク析出量にもかかわら ず，入口原料モル分率が増加するにつれて劣化の度合は増加す ることが図からわかる。原料濃度を増加すると、コークは高分 子量になるが，コーク自身の性状はほとんど同じであることが

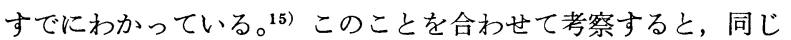
コーク生成量でる入口原料モル分率が大きい程, 高分子量のコ 一クが細孔入口付近に析出すると思われ，それが細孔閉そくを 起こすと, 細孔内部の活性点は生きているが使えない状態で, これを細孔入口閉そくと称する。逆にモル分率が小さいと，低 分子量のコークが細孔内に比較的均一に析出して, 活性点を薄 く伸びやかに被覆していると考兄られる。これを均一被覆と称 する。つぎに, 反応温度が上昇すると，アセトアルデヒド生成 速度は変化をらけた。14) しかし, 劣化の度合は Fig. 2 に示し ているように同じであった。これはコークにより被覆される活 性点の絶対数が温度上昇と共に増加するが, 同時に被覆速度も 速くなるので, 単位活性点当たりの被覆速度が一定となり，乙 かも被覆状態（析出過程）が同一であることによると考えられ る。したがって, 劣化係数 $\alpha$ の入口原料モル分率 $Z_{\mathrm{E} . \mathrm{o} .}$. のみの 相関を求めたところ, 相関係数 0.997 で直線関係が得られたの で, アセトアルデヒド生成反応の劣化関数は次のようになっ た。

$$
\varphi_{\mathrm{A}}=\exp \left\{-\left(2.10 Z_{\text {E.o. }}+0.288\right) C_{\mathrm{C}}\right\}
$$

\section{$3 \cdot 2$ コーク生成量の表式化}

コーク生成量 $C_{\mathrm{C}}$ は流通時間, 濃度, 接触時間, 反応温度な どの反応操作因子によって表式化されらる。まず，コーク生成 量と流通時間との関係を求めたのが Fig. 3 である。Voorhies 1 )

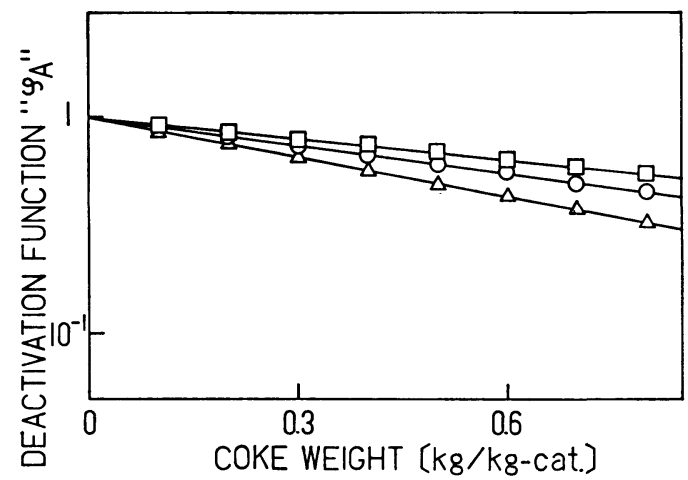

Fig. 2 Dependence of Deactivation Function $\varphi_{A}$ on Coke Weight with Ethylene Oxide Mole Fraction $(\square: 0.20, \bigcirc: 0.35, \triangle: 0.50)$ and Reaction Temperature $(493 \sim 573 \mathrm{~K})$ [There was the same tendency to reaction temperature. Other experimental conditions: catalyst weight of 0.402 $\mathrm{g}$, and $\mathrm{W} / \mathrm{F}$ of $0.372 \mathrm{~g}$-cat $\cdot \mathrm{hr} / \mathrm{mol}]$ 


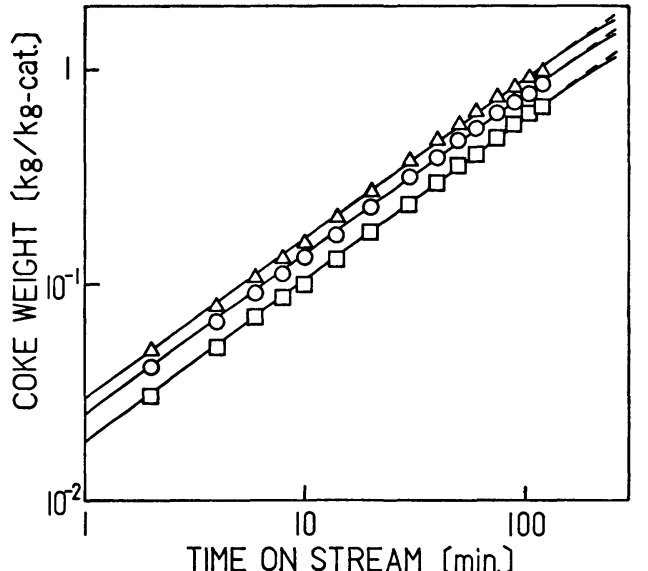

Fig. 3 Coke Weight as a Function of Time on Stream with E.O. Mole Fraction $(\square: 0.20, \bigcirc: 0.35$, $\triangle: 0.50)$ is Expressed as $C_{\mathrm{c}} \propto \theta^{0.75}$ within the Coefficient of Variation of $1.3 \%$ [Other conditions are similar to these in Fig. 2 except for reaction temperature of $493 \mathrm{~K}$ ]

と同様に、コーク生成量は流通時間のベキ乗に比例した。そし て入口原料モル分率の増加に伴いコーク生成量は増加するにも かかわらず，流通時間のべキ数は一定となり，493K において 変動係数 $1.3 \%$ で 0.75 乗となった。この傾向は $493 \mathrm{~K}$ 以外の 温度でも同様になり, それぞれ $533 \mathrm{~K}$ で 0.62 乗, $573 \mathrm{~K}$ で 0.47 乗となった。これら温度変化に伴らコーク生成量の変化 を Fig. 4 に示した。Voorhies') は反応温度上昇とともにコー ク生成量が増加することを明らかにしている。その後 Ozawa と Bischoff(4) る同様な結果を報告している。しかしながら, 本 報においてはいささか特異的であった。反応初期において, ב 一ク量は反応温度上昇とともに增加し, 上記文献の傾向と一致 している。このとさ, コークによる活性点被覆状態は, Fig. 2 に拈いて入口原料モル分率の小さい時に起こっていると考察し た均一被覆に相当する。しかし，約 5 分前後以後において，コ

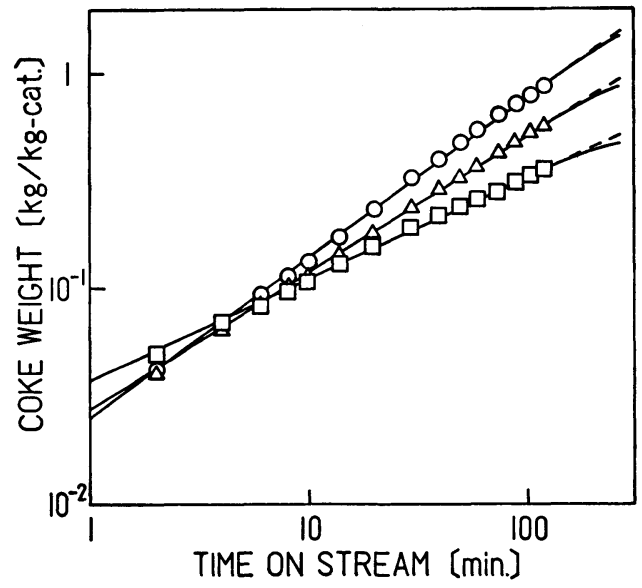

Fig. 4 Relation of Coke Weight to Time on Stream at Different Reaction Temperatures $(O: 493 \mathrm{~K}$, $\triangle: 533 \mathrm{~K}, \square: 573 \mathrm{~K}$ ) [Other conditions are similar to these of Fig. 2 except for E.O. mole fraction of 0.35 ]
ーク量は反応温度上昇とともに減少している。このとき，入口 原料モル分率が比較的高ければ, コークは Fig. 2 において考 察した細孔入口閉そくを起こしていると思われる。るし入口原 料モル分率が比較的低ければ，均一被覆の進行の結果生じる閉 そくによって，細孔内部までュークでつまっていると思われ る。これを細孔均一閉そくと称する。Dadyburjor ${ }^{18)}$ はコーク による活性点被覆には現象学上二通りあり, 一つは直接サイト 抑制であり，もう一つは細孔閉そくであると提言している。直 接サイト抑制は本報の均一被覆に相当し, 細孔閉そくは本報の 細孔入口閉そくに相当する。さらに 120 分以後 10 時間までの 実験において、ニーク量は直線より低下しつつ増加していく。 この現象は粒子外表面のみに, あるいは粒子間にコークが析出 していることを示唆している。以上の挙動はコーク生成量ばか りでなく，酸化ェチレン消費速度またはアセトアルデヒド生成 速度からも裏付けられる。14) また，流通時間のべキ数の温度依 存性は次のように表すことができた。

$$
n=-3.50 \times 10^{-3} T+2.49
$$

さらに Fig. 3 から, コーク生成量と入口原料モル分率との関 係は，Fig. 5 に示したように反応温度にかかわらずこう配が 一定となり，0.52 といらべキ数を得た。このことからコーク 生成量は，つぎの関係式で表現することができた。

$$
C_{\mathrm{c}}=B \theta^{n} Z_{\mathrm{E} .0 .{ }^{0.52}}
$$

つぎに, コーク生成量と反応温度との関係は，すでに流通時 間のべキ数として一部取り入れられているが，各流通時間にお いて, コーク生成量の対数と反応温度の逆数とに対してよい比 例関係があった。これより Eq. (4) のBは, 反応温度の逆数 に対して Fig. 6 のようになった。一方, ニーク生成量の接触 時間に対する影響は $\mathrm{W} / \mathrm{F}=0.559 \mathrm{~g}-\mathrm{cat} . \mathrm{hr} / \mathrm{mol}$ 以下の実験範 囲内において認められなかった。

以上の結果から，酸化ェチレン異珄化反応におけるコーク生 成量は次式で表現することができた。 $n$ は Eq. (3) に示し た。

$$
C_{\mathrm{c}}=(0.785) \theta^{n} Z_{\mathrm{E} .0 .} .^{0.52} \exp \left(\frac{-1.46 \times 10^{3}}{T}\right)
$$

変動係数は $0.95 \%$ であった。入口原料モル分率 0.35 , 反応 温度 $493 \mathrm{~K}, \mathrm{~W} / \mathrm{F}=0.372 \mathrm{~g}-\mathrm{cat} . \mathrm{hr} / \mathrm{mol}$ に打ける実測值と Eq.（5）の計算值との比較を Fig. 7 に示した。これは非常 によい一致を示し，他の実験条件においても同様な一致がみら

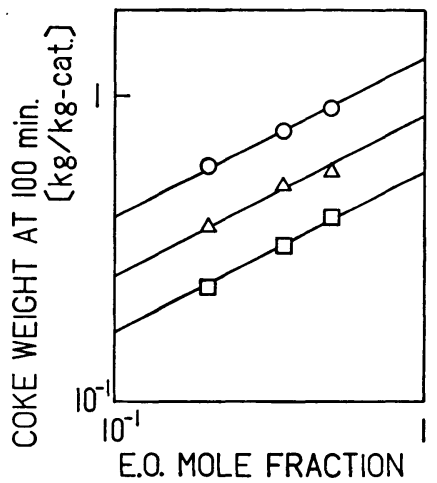

Fig. 5 Relationship between Coke Weight at $100 \mathrm{~min}$ and E.O. Mole Fraction at Different Reaction Temperatures $(O: 493 \mathrm{~K}, \triangle: 533 \mathrm{~K}, \square: 573 \mathrm{~K}$ ) 


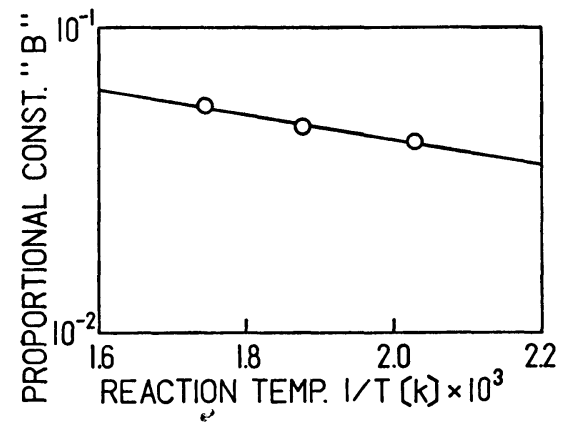

Fig. 6 Relationship between "B" in Eq. (4) and Reaction Temperature

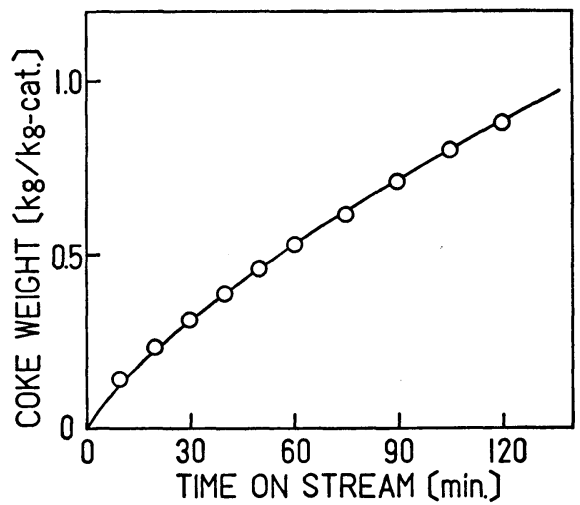

Fig. 7 Comparison of Experimental and Calculated Results [Experimental conditions: E.O. mole fraction, 0.35 ; reaction temperature, $493 \mathrm{~K}$, catalyst weight, $0.402 \mathrm{~g}$; and $\mathrm{W} / \mathrm{F}, 0.372 \mathrm{~g}$-cat. $\mathrm{hr} / \mathrm{mol}]$

れたことから，表式化した Eq.（5）の妥当性を示していると 考えた。コーク生成量が全操作因子により表式化されたことに より，Eq.（2）で表現された主反応劣化関数は全操作因子に より表式化された。

\section{3 アセトアルデヒドから生成するコーク}

シリカーアルミナ系触媒上での酸化エチレン異性化反応は, コ ーキング反応により劣化することはすでに述べた。コーク生成 原料となるのは反応成分以外飞生成成分がある。そこで, 生成 物であるアセトアルデヒドのみを供給して反応させたところ, 触媒重量は増加してコークが生成することを認めた。したがっ て, 酸化エチレン異性化反応によって生成されるコークは, 酸 化エチレンから直接生成されるコークと, 生成物のアセトアル デヒドから生成されるコーク（以下アルデヒドコークと呼ぶ） の 2 種類あることが明らかとなった。しかしながら，アルデヒ ドューク生成量は, 酸化エチレン異性化反応時のコーク量と比 べて極端に少なく約 1 割程度であった。アルデヒドュークにつ いても，異性化反応時に生成するコークと同じ手法により表式 化を試みた結果, 次式を得た。

$$
\begin{aligned}
& C_{\mathrm{c}}{ }^{\prime}=\left(8.99 \times 10^{-3}\right) \theta^{n^{\prime}} Z_{\mathrm{AcA}} \mathrm{A}^{0.51} \exp \left(\frac{1.16 \times 10^{3}}{T}\right) \\
& n^{\prime}=1.00 \times 10^{-3} T+2.06 \times 10^{-1}
\end{aligned}
$$

変動係数は $3.2 \%$ であった。異性化反応時に生成するアセトア ルデヒドのモル分率オーダを考慮して, 0.03 における実測值

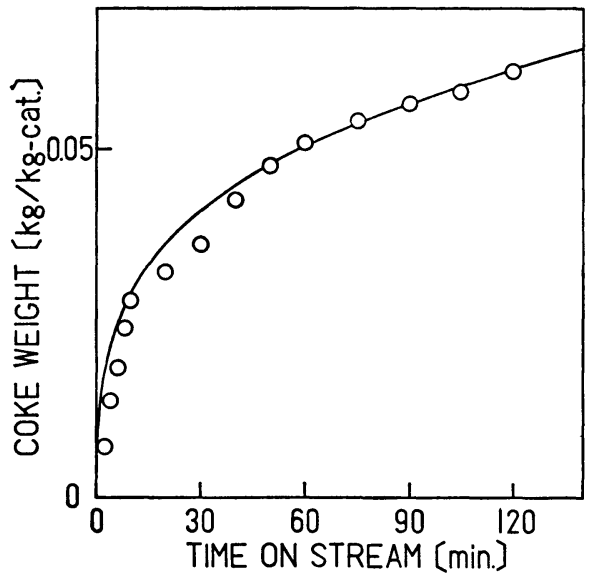

Fig. 8 Comparison of Experimental and Calculated Results [Conditions are similar to these of Fig. 7 except acetoaldehyde mole fraction of 0.03]

と Eq. (6) の計算値との比較を Fig. 8 に示した。よい一致 が得られ，Eq. (6) の妥当性をみた。

異性化反応時に生成するコークとアルデヒドュークは，分析 の結果前者中にも後者が多少存在する程度であり, 両者は違ら 性質のコークと考えてよいことがわかった。15）しかしながら， 表式化において両者に共通な実験式で表され，その評価もまっ たく同様に行えることは興味深い。コーク自身の性質により俰 数や定数が異なるだけで, ニーク生成量の表式化は本報の手法 により広く一般にも適応されるものと考光る。

\section{4. 結 言}

シリカーアルミナ系触媒上での酸化ェチンン異性化反応は, 触 媒上に析出するコークにより触媒劣化を生じる。その主反応劣 化関数を各操作因子により Eq. (2) で表式化することができ た。この劣化関数導出に拈いて, ニークの均一被覆と細孔均一 閉そくあるいは細孔入口閉そくとにより, 触媒劣化現象が生じ ることが認められると同時に, 劣化関数が触媒の反応性をも表 現しらることが明らかとなった。均一被覆は反応初期や供給濃 度の薄い時など, 総じて供給量の少ない時に起こる。細孔均一 閉そくは供給濃度が薄く，比較的時間を要しないと一定の供給 量にならない時に起こる。細孔入口閉そくは, 供給濃度が濃く て短時間に一定の供給量に達する時に起こると思われた。ま た，今まで生成コークの全操作因子による表式化が行われてい なかったが，Eq.（5 ) により表式化できた。この式はアルデ ヒドコークでも同様の式で得られたことにより、コーク自身の 性質が異なっても Eq.（5）の型で整理されると思われる。

\section{Nomenclature}

$\begin{aligned} C_{\mathrm{C}}: \text { coke weight } & (\mathrm{kg} / \mathrm{kg}-\mathrm{cat}) \\ F: \text { feed rate } & (\mathrm{mol} / \mathrm{hr}) \\ r: \text { reaction rate } & (\mathrm{mol} / \mathrm{hr} \cdot \mathrm{g} \text {-cat }) \\ T: \text { reaction temperature } & (\mathrm{K}) \\ W: \text { catalyst weight } & (\mathrm{g}) \\ Z: \text { mole fraction } & (-) \\ \alpha: \text { deactivation coefficient } & (-) \\ \varphi: \text { deactivation function } & (-)\end{aligned}$


$\theta:$ time on stream $\quad(\min )$

\section{Suffix}

$0:$ initial

E.O. : ethylene oxide AcA. : acetoaldehyde

\section{References}

1) Voorhies, A., Ind. Eng. Chem., 37, 318 (1945).

2) Pachovsky, R. A., Ind. Eng. Chem. Process. Des. Develop., 12, 254 (1973).

3) Beeckman, J. W., Froment, G. F., Ind. Eng. Chem. Fundam., 18, 245 (1979).

4) Ozawa, Y., Bischff, K., Ind. Eng. Chem. Process. Des. Develop., 7, 67 and 72 (1968).

5) Rollman, L. D., J. Catal., 47, 113 (1977).

6) Rollman, L. D., Walsh, D. E., J. Catal., 56, 139 (1979).

7) Venuto, P. B., Hamilton, L. A., Ind. Eng. Chem. Process. Des. Develop., 6, 190 (1967).
8) Haldeman, R. G., Botty, M. C., J. Phys. Chem., 63 , 489 (1958).

9) Sedran, U. A., Comelli, R. A., Figoli, N. S., Applied Cat., 11, 227 (1984).

10) Echigoya, E., Nemoto, Y., Morikawa, K., Sekiyu Gakkaishi, 7, 406 (1964).

11) Murahashi, S., Imoto, M., Tani, H., "Synthetic Polymer (合成高分子) IV”, (1975) Asakura Syoten (朝倉書店)。

12) Sakai, T., Ishii, Y., Kogyo Kagaku Zasshi, 62, 413 (1959).

13) Merrill, G. T., Latremouille, G. A., Eastham, A. M., Can. J. Chem., 38, 1967 (1960).

14) Takasaki, Y., Tachikawa, N., Sekiyu Gakkaishi, to be submitted.

15) Takasaki, Y., in preparation.

16） Tanaka, H., Dr. thesis（膠質土の本体とその化学的利 用に関する研究), Waseda Univ. (1970).

17) Anderson, R. B., Ind. Eng. Chem., 53, 1011 (1961).

18) Dadyburjor, D. B., J. Catal., 79, 222 (1983). 


\title{
Summary
}

\section{Simulation of Goke Deposition in Isomerization of Ethylene Oxide}

\author{
Yuukei Takasaki, Norio Tachikawa ${ }^{\dagger 1)}$, and Noburu Sakuma ${ }^{\dagger 2}$ \\ Department of Industrial Chemistry, Faculty of Engineering, Utsunomiya University \\ Ishii-cho, Utsunomiya 321 \\ †1) Denkikagaku Kogyo Co., Ltd., Oomi-cho, Nishikubiki-gun, Niigata 949-03 \\ †2) Tōyō Ink Co., Ltd., Nakafukumatsumine, Kawagoe 356
}

It often happens that hydrocarbon reacts to form coke deposit on silica-alumina catalysts. In this paper, the isomerization reaction of ethylene oxide was carried out on a catalyst made of Japanese colloidal earth pretreated with hydrochloric acid. It was quantitatively examined how the behavior of coke deposition would be influenced by the individual operational factors.

Isomerization of ethylene oxide formed acetoaldehyde, and, at the same time resulted in deposition of coke on the catalyst (Fig. 7). When catalyst deactivation is taken into account, the reaction rate can be expressed by Eq. (1). The deactivation function $\varphi$, an effective measure of the decaying reaction rate, can be expressed as the ratio of the initial reaction rate and that in a later stage of reaction. In this system, it was correlated as $\varphi=\exp \left(-\alpha C_{\mathrm{c}}\right)$. This was considered to be dependent on individual operational factors and the functional forms were determined.

First, the deactivation coefficient $(\alpha)$ which indicates the degree of deactivation was not dependent on the reaction temperature, but it was dependent on the feed concentration (Fig. 2). When the feed concentration was high, coke of large molecular weight deposited at the open ends of the pores causing the loss of active sites. In contrast, when the feed concentration was low, the inner walls of the pores were thinly and evenly covered with coke of low molecular weight. Thus, the deactivation coefficient remained unchanged because the de- position rate per unit active site remained constant even when the reaction temperature was raised.

Next, the weight of the coke deposited was proportional to 0.52 power of feed concentration (Fig. 5) and to some power of time on stream (Fig. 3), depending on the reaction temperature (Eq. (3)). In the initial stages of the reaction, the weight of coke increased with rising reaction temperature (Fig. 4). It was considered that the active sites were covered uniformly with coke. About 5 minutes later, the weight of coke began to decrease in spite of rising reaction temperature (Fig. 4). It was observed that, for lower feed concentrations, a uniform coverage of the pores resulted from coke deposition, and with higher concentrations, a direct blockage of the open ends of the pores resulted. About 120 minutes later, coke began to deposit between and among the particles (Fig. 4). The weight of coke was not affected by W/F; as a result it could be formulated by Eq. (5), indicating that the deactivation function could be expressed as a function of each operational factor.

Furthermore, the coke formed from acetoaldehyde, differed from that formed in the isomerization reaction of ethylene oxide. The weight of coke, however, could be related to Eq. (6), which is similar to Eq. (5). Only the constant of Eq. (5) changed depending on the nature of the coke. From these facts it can be concluded that the method shown in this paper is generally acceptable.

\section{Keywords}

Coke, Deactivation, Ethylene oxide, Isomerization, Japanese colloidal earth, Silica alumina catalyst 